\title{
Etiudy animowane Grzegorza Wacławka
}

\author{
ADAM DOMALEWSKI \\ Instytut Filmu, Mediów i Sztuk Audiowizualnych \\ Uniwersytet im. Adama Mickiewicza w Poznaniu
}

\begin{abstract}
Domalewski Adam, Etiudy animowane Grzegorza Wacławka [Animated etudes by Grzegorz Wacławek]. „Images” vol. XX, no. 29. Poznań 2017. Adam Mickiewicz University Press. Pp. 323-328. ISSN 1731 450X. DOI 10.14746/i.2017.29.20.

The author considers in the paper three animated etudes made by Grzegorz Wacławek in Film School in Łódź. Films entitled Gleam, Scrap and Lost share many common features: creation of the hero's outer world, extensive use of symbolism and condensation of events centered around one or two heroes. Particularly interesting mean used by Wacławek in endings of the films is the transformation of the presented world that can be named a scale change. Also on this basis director's animations are metaphorically interpreted, showing their existential meaning, close to the tradition of Polish Animation School.
\end{abstract}

KEYWORDS: animation, animated film, Grzegorz Wacławek, Polish Animation School, film - philosophy

Grzegorz Wacławek to reżyser i producent, absolwent Wydziału Operatorskiego Państwowej Wyższej Szkoły Filmowej, Telewizyjnej i Teatralnej w Łodzi. Założyciel studia filmów animowanych Animoon, obecnie także prezes Stowarzyszenia Producentów Polskiej Animacji, jeszcze $\mathrm{w}$ trakcie studiów zrealizował trzy ciekawe krótkometrażowe filmy animowane: Iskre (2006), Kawałek (2007) oraz etiudę Zagubiony (2008). Obrazy te warte są uwagi ze względu na rosnącą z roku na rok wartość artystyczną oraz podejmowaną przez twórcę problematykę - bliską ,filozoficznej” tradycji polskiej szkoły animacji. W niniejszym artykule analizuję powracające u Wacławka tematy oraz motywy fabularne, a także ukazuję możliwe sposoby metaforycznego odczytania poszczególnych etiud. Już na wstępie można bowiem zaznaczyć, że twórca rezygnuje $\mathrm{w}$ swoich filmach z wprowadzania dialogów, kształtując animowane światy przedstawione wyłącznie za pomocą obrazu i dźwięku. Wykorzystuje przy tym autorską technikę, polegającą na skanowaniu i komputerowym animowaniu rzeźb ceramicznych. Ważną rolę w pracach reżysera odgrywa też muzyka autorstwa jego stałej współpracowniczki - Magdy Grabowskiej.

\section{Niestabilny świat}

Tym, co najsilniej wpływa na bohaterów etiud Wacławka, jest niestabilność otaczającego ich świata. Wykreowana w animacjach twórcy rzeczywistość na różne sposoby wywołuje w widzu poczucie zmienności i chwiejności zdarzeń. W Iskrze efekt ten osiągnięty zostaje za pomocą kontrastów - jasny, pełen kolorów i ciepła, radosny świat chłopca zderzony zostaje $\mathrm{z}$ brunatnym, gęstym, nieprzejrzystym wnętrzem domu starego człowieka[1]. Obok zestawienia idyllicznych obrazów natury, której doświadcza młody bohater, z ponurą izbą skupionego na struganiu $\mathrm{w}$ drewnie staruszka funkcjonuje także swoisty dialog $\mathrm{w}$ warstwie muzycznej. Wysoki, spokojny, choć też smutny śpiew chłopięcy spotyka się ze zdecydowanie bardziej dramatycznym, podniosłym śpiewem

[1] W tych fragmentach animacji wizualność i nastrój przywodzą na myśl styl Piotra Dumały z jego adaptacji Łagodnej (1985) oraz Zbrodni $i$ kary (2000) Fiodora Dostojewskiego. Zob. rozdział „Sny Piotra Dumały” w pracy Marcina Giżyckiego, w którym autor charakteryzuje technikę filmową wymyśloną przez Dumałę - opartą na animacji rysunków uzyskiwanych na gipsowych płytach (Giżycki 2000, s. 101-105). 
męskim. Oba głosy intonują podobną melodię, jednakże nasycają ją całkiem inną emocjonalnością. Uzyskiwany dzięki temu kontrastowy efekt charakteryzuje oczywiście odpowiednio obu bohaterów oraz związane $\mathrm{z}$ ich wiekiem odmienne doświadczenia; zestawienie to ilustruje jednak także niepokojącą niestabilność przedstawionego świata. Zapadająca na końcu cisza nie unieważnia tego efektu, a wręcz przeciwnie - podkreśla powiązanie ze sobą różnych etapów ludzkiego życia (zwłaszcza że w trakcie napisów końcowych oba głosy powrócą, po raz pierwszy śpiewając jednocześnie).

Chybotliwość - $\mathrm{i}$ to rozumiana dosłownie jest jedną z głównych cech świata przedstawionego w Kawałku. Tajemnicze drewniane wnętrze, w którym przebywa bohater, od początku, sprawia wrażenie mechanizmu wprawionego w ruch: nad stołem kołysze się - to w jedną, to $\mathrm{w}$ drugą stronę - naftowa lampa; nadto wzdłuż ścian zamontowane są wymyślne, wykonane $\mathrm{z}$ drewna koła zamachowe, tworzące poruszający się swoim rytmem mechanizm. Jego ruch zdaje się ulegać wygaszeniu, mimo to wlatujący nagle do wnętrza ptak ginie, wpadając pomiędzy poruszające się wolno zębatki, choć sam moment wypadku nie zostaje nam bezpośrednio ukazany. Dwa elementy w środku poruszającej się izby opierają się wymuszanemu na nich ruchowi: są to duży kaflowy piec i pracujący przy stole bohater. O podtrzymaniu tego ruchu decyduje zaś wrzucenie do żarzącego się pieca modelu statku powietrznego, sklejonego przez mężczyznę z kawałków drewna. Mechanizm natychmiast powraca do szybkiej pracy, wrażenie pędu potęguje perkusyjna muzyka, a na ukazanej w zbliżeniu twarzy bohatera pojawia się uśmiech. Tak więc niestabilność w Kawat$k u$ utożsamiona zostaje $\mathrm{z}$ ożywczym ruchem $\mathrm{i}$ - inaczej niż $\mathrm{w}$ dwóch pozostałych animacjach - waloryzowana jest pozytywnie, choć i $z$ nią wiąże się pewne zagrożenie.

$\mathrm{W}$ ostatniej $\mathrm{z}$ trzech analizowanych przeze mnie etiud niestabilność ustępuje miejsca wrażeniom pustki, bezruchu, wyobcowania i przygnębienia. Chłopiec będący bohaterem Zagubionego przemierza niby-skalistą pusty- nię, w której spotyka tylko ptaki żyjące wysoko w górze jednej z pieczar. W tajemniczy sposób zjawia się naprzeciw niego także milczący mężczyzna, obdarzony nadnaturalnymi możliwościami, już po chwili pracowicie zapisujący kolejne karty przy swoim biurku. Aurę nieprzewidywalności i chwiejności budują w przypadku tej animacji przede wszystkim nagłe pojawianie się i znikanie przedmiotów oraz przemiany materii ożywionej w nieożywioną i na odwrót. Za sprawą dotknięcia mistrza czarny kamień materializuje się w jego dłoni w postaci gołębia. W końcowej scenie, gdy chłopiec siedzi przy tym samym biurku, przy którym siedział skryba, jego ręce usychają i odpadają kawałkami jak rozbita glina. Znaczenie tych obrazów postaram się wyjaśnić w dalszej części artykułu; $w$ tym miejscu ważne, moim zdaniem, jest podkreślenie, że zewnętrzny wobec bohaterów świat jest $\mathrm{w}$ animacjach Wacławka zawsze w jakiś sposób niestabilny i wrogi. Nieprzyjazny charakter otoczenia pozostaje niezależny od ich woli, ale trudna i nieprzychylna rzeczywistość daje się odkształcać i przynajmniej częściowo zmieniać.

\section{Forma i symbole}

Nie da się ukryć, że Iskra - najwcześniejsza spośród analizowanych etiud - zdradza jeszcze pewne braki warsztatowe. Animacja mogłaby być krótsza; niektóre sceny są nadmiernie wydłużone, zwłaszcza gdy weźmie się pod uwagę fakt, że Wacławek często operuje niemal statycznymi kadrami, w których animacji podlegają pojedyncze elementy świata przedstawionego. Zdarza się także, że sam ruch pozbawiony jest lekkości, sprawia wrażenie mechanicznego - na przykład w scenie, w której chłopiec siedzi na gałęzi drzewa i podrzuca do góry patyk. Podobnie dzieje się też na początku etiudy, gdy bohater odbiega od głaskającej go matki. Lepiej prezentują się fragmenty ukazujące struganie w drewnie łódki przez starszego mężczyznę chociaż one także są przeciągnięte, to jednak za sprawą towarzyszącego im śpiewu, gęstości faktury i barwy budują duże napięcie. Zaledwie o rok późniejszy Kawałek stanowi już poważ- 
ny dowód uzyskania przez twórcę biegłości w dziedzinie animacji. Wacławek używa w tej etiudzie znacznie większej skali środków: od fragmentów spokojnych, w których w obrębie kadru zaznaczone zostają pojedyncze zmiany, po nagłe rozkołysanie obrazu, gdy w ruch puszczona zostaje latająca maszyna zaraz po wrzuceniu do pieca jej drewnianego modelu. Dzięki temu film wydaje się nieporównanie bardziej zróżnicowany i dynamiczny od poprzedniego. Zagubionego zaś wypada uznać za świadectwo twórczej dojrzałości reżysera - narracja tej etiudy jest zdyscyplinowana, a wszystkie filmowe środki podporządkowane zostały opowiadanej historii. Autor przekonująco używa bogatej palety barw, choć dominują w niej żółcie i brązy. Dramaturgię animacji buduje też oczywiście muzyka, wyjątkowo dobrze kreująca tu zmienne, zestrojone $\mathrm{z}$ treścią kolejnych obrazów nastroje.

Etiuda $\mathrm{z}$ roku 2008 przewyższa wcześniejsze jeszcze jednym, trudnym do przeoczenia komponentem: skalą wykorzystania wymownych symboli. Wydaje się, że - wobec całkowitej rezygnacji z dialogów - jakakolwiek próba interpretacji Zagubionego oprzeć się musi na analizie bogatej symboliki warstwy obrazowej. Lista wykorzystanych w filmie znaków, cechujących się długotrwałą obecnością w wyobraźni literackiej i malarskiej kultury Zachodu, jest naprawdę długa - kamienne tablice, gołębie, lustra, pióro i złoto to najważniejsze $\mathrm{z}$ nich. Znaczenia konotowane przez powyższe symbole upewniają zaś w możliwości alegorycznego odczytania filmu w duchu religijnym, choć - jak przekonuje w swej książce Magdalena Kempna-Pieniążek:

O tym, czy dany film zostanie uznany za chociażby potencjalnie religijny, decydują czynniki jak najbardziej subiektywne; innymi słowy, religijność filmu jest czymś, co poniekąd rodzi się w kontakcie dzieła $\mathrm{z}$ reprezentującym określone wartości i odpowiednio przygotowanym odbiorcą. (Kempna-Pieniążek 2013, s. 50-51)

Wydaje się, że majestatyczne atrybuty (kamienne tablice, złoty pył) i stwórcze działania (wzbudzenie gołębicy) zjawiającego się mężczyzny pozwalają widzieć w nim figurę Boga, zaraz jednak dodać trzeba, że wizja zawarta w Zagubionym daleka jest od religijnej ortodoksji i skupia się na trudnych relacjach między występującymi w filmie postaciami. W pierwszych scenach widzimy więc chłopca cierpiącego udrękę z powodu otaczającej go pustki, co można interpretować jako trawiącą go tęsknotę za absolutem. Potrzeba spotkania $z$ wyższym bytem na gruncie duchowym jest tak silna, że bohater sam ewokuje jego postać. Niewiele znaczące ruchy ręką w dolnych partiach skalistej pieczary, na której przebywają ptaki, sprawiają że przed chłopcem zjawia się niespodzianie najpierw twarz, a potem cała sylwetka Innego. Przybysz nie okazuje się jednak, przynajmniej $\mathrm{z}$ pozoru, szczególnie pomocny albo zainteresowany losem nieszczęśliwego, zagubionego młodzieńca. Byt ten zatroskany jest raczej swoimi sprawami, wytrwale zapisuje kolejne stronice niczym mające nadejść dzieje.

Chłopiec bacznie obserwuje pracującego towarzysza, ale nie widzi szansy, by się do niego zbliżyć. Mimo łudzącej bliskości, zagadkowa postać nie daje się poznać inaczej niż w swoich działaniach, pozostaje odległa i milcząca. Co znamienne, chłopiec spogląda to w nią, to w lustro, szukając w obu swego odbicia i zarazem próbując zrozumieć własną istotę. Zrozumienie nie jest jednak łatwe, a może wręcz w ogóle nie jest możliwe, zwłaszcza że za chwilę zdezorientowany bohater staje się świadkiem czegoś na kształt cudu - w rękach siedzącego przy biurku mężczyzny kamień zamienia się w gołębia, który majestatycznie wzlatuje ku górze. Ta nagła przemiana wywołuje uśmiech tylko na twarzy stwórcy, przestraszony świadek wydarzenia odchodzi w swoją stronę, a przygarbiony staruszek odprowadza go wzrokiem $\mathrm{z}$ wysokości krętych schodów. Jeśli więc Zagubiony za pomocą ciekawie wykorzystanej, choć nieco zmurszałej, symboliki obrazować ma relację Boga i człowieka, to ukazuje ją w barwach dość ponurych. Samotność stwórcy dorównuje w tej wizji samotności ludzi; nadto Bóg wydaje się odległy, niepoznawalny, nieomal obojętny, choć wyczarowany przez niego ptak czekać potem będzie na chłopca i usiądzie mu na ramieniu. Ten 
ostatni obraz można oczywiście odczytywać jako znak duchowej łączności i łaski płynącej od czuwającej nad bohaterem opatrzności, która choć z pozoru odległa i obca - nie pozostaje całkiem niewzruszona jego dalszymi losami.

\section{Zmiana skali}

Etiuda nie kończy się jednak tak optymistycznie. Po długim wyciemnieniu w trzech kolejnych, coraz bardziej dalekich, kadrach widać siedzącego nieruchomo przy stole bohatera z ptakiem na ramieniu. Najbardziej uderzające jest jednak to, że wyciągnięte do przodu ręce postaci zaczynają kruszeć i odpadać od reszty ciała. W ten sposób docieramy do bodaj najciekawszej, najbardziej frapującej cechy łączącej etiudy Wacławka, którą chciałbym nazwać z mianą skali. Oczywiście, transformacja animowanych obiektów jest czymś swoistym dla filmu animowanego, można nawet powiedzieć - jego kwintesencją. Marcin Giżycki w podobnym kontekście pisze o tym, że animacja służy pragnieniu „nie reprodukowania życia, tylko uwolnienia wytworów wyobraźni” (Giżycki 200o, s. 7). W innym zaś miejscu dodaje:

Film animowany niewątpliwie bardziej niż jakakolwiek inna sztuka zbliża się do natury snu. W filmie fabularnym, aktorskim, jak to powiedziano kiedyś w tytule znanej książki o trikach filmowych, „nie ma rzeczy niemożliwych" [...], niemniej wszelkie metamorfozy, transformacje odbieramy zawsze jako coś nadnaturalnego, $\mathrm{z}$ innego świata, świata fikcji. W snach i w animacji natomiast fantastyka jest czymś naturalnym, oczywistym. (Giżycki 2000, s. 103)

Jednakże w omawianych realizacjach pomysły wykorzystane przez twórcę, zwłaszcza w filmowych epilogach, wykraczają poza schemat nagłej i nieoczekiwanej metamorfozy bohatera lub świata przedstawionego. Przemiana dokonująca się w finałach opowiadanych historii okazuje się głęboko i kunsztownie powiązana

[2] Warto dodać, że po ukończeniu PWSFTviT zadebiutował on w roku 2010 filmem zatytułowanym Poza starościa. z wcześniejszymi wydarzeniami oraz wprowadzonymi uprzednio motywami ikonicznymi. W ten sposób krótkie wszak filmy Wacławka zyskują cały szereg dodatkowych, zwykle niepokojących znaczeń.

W Iskrze motywem przewodnim, który pozwala wprowadzić do filmu sugestywną zmianę skali, stają się drewniane łódki. W kontrastowo zestawionych ze sobą światach - dziecka i staruszka - zajmują one obydwu bohaterów: chłopiec puszcza łódki na rzece, leżąc na pomoście i ciesząc się letnią pogodą. Starszy pan w swoim ciemnym pokoju struga natomiast modele w drewnie i odkłada je na półkę. W ostatniej scenie przygarbiona postać wstaje ze swego fotela, podchodzi do okna i widzi zacienioną sylwetkę chłopca, siedzącego w łódce i odpływającego w dal. Barwy użyte do zakomponowania wieńczących etiudę kadrów pokrywają się z tymi, które charakteryzowały wnętrze domu staruszka. Przesłanie wydaje się dość czytelne Iskra wymownie ukazuje przemijanie młodości, która jest jednak nieustannie przeżywana nawet w starości. Zespolenie skrajnych etapów życia w jednej przejmującej wizji udaje się także dzięki finałowej zmianie skali, w wyniku której chłopiec mieści się we wnętrzu małej łódki. Wacławek tym rozwiązaniem jednocześnie domyka „do środka” wykreowany świat, stapia go w rodzaj metaforycznego obrazu na temat pospiesznego upływania życia i opierających się temu wspomnień. Starość jest zresztą jednym z najczęściej powracających tematów w jego twórczości[2].

Motyw tworzenia w drewnie modelu-zabawki powraca także w Kawałku - tym razem bohater skleja $\mathrm{z}$ wielu rozsypanych elementów makietę statku powietrznego. Jak już wspominałem, wrzucenie do ognia gotowego modelu ponownie rozpędza cały znajdujący się we wnętrzu izby mechanizm. Następuje wtedy świetnie wykonane, dynamiczne ujęcie, w którym zmienia się cała perspektywa widza - po odbiciu obrazu od futryny okna o 180 stopni $z$ wolna ukazuje się oglądającemu wizja lecącego w szarych przestworzach statku. Statek ten niezbicie przypomina kształtem, barwą oraz sposobem 
poruszania się wrzucony do ognia model. Ponownie więc Grzegorz Wacławek zaskakuje odbiorcę nieoczekiwaną transformacją wykreowanego w animacji świata, opartą na zmianie skali, w której świat ten jest ukazywany. Zakończenie Kawałka odwołuje się tym samym do najlepszych tradycji polskiego filmu animowanego oraz przypomina o „specjalności polskiej animacji lat pięćdziesiątych i sześćdziesiątych, jaką były animowane powiastki filozoficzne $z$ elementami głębokiej refleksji o życiu i świecie" (Hendrykowski 1998, s. 55). Jak dodaje, pisząc o tym samym okresie, Paweł Sitkiewicz,

[...] filmowcy próbowali przełożyć dylematy współczesnego człowieka na mikronarracje zakończone mocną puentą, która albo stawiała pytanie o los bohatera, albo zawierała ogólną refleksję na temat ludzkiej egzystencji. (Sitkiewicz 2011, s. 167)

Zakończenie Kawałka pozostaje niepokojąco niejednoznaczne i przypominać wręcz może Schody (1968) Stefana Schabenbecka, na pewno jednak spowija je „egzystencjalna aura”, o której pisze Sitkiewicz. Oto bowiem cały wysiłek bohatera, utożsamiany tu $\mathrm{z}$ tym, co cierpliwie i pieczołowicie tworzy, ląduje $\mathrm{w}$ piecu po to tylko, by podtrzymać ruch, a więc i życie, w mikrokosmosie, który okazuje się niczym więcej, jak tylko znacznie powiększonym, wypracowanym już wcześniej i przewidzianym modelem. Przetrwanie uwarunkowane więc jest zniszczeniem, spaleniem, obróceniem w niwecz własnego trudu, którego jednak nie można się wyrzec. Kawałek obrazować zatem może heroizm codziennej egzystencji, a także jej uwięzienie we własnym niepewnym projekcie. Może być też stosunkowo mniej pesymistyczną ilustracją porzekadła „jesteś tym, co robisz”.

Zmiana skali, uniemożliwiająca zbyt łatwy odbiór zakończenia animacji przez odbiorcę, pojawia się także w Zagubionym. Wspomniane odpadanie od ciała kolejnych kawałków kruszejących na oczach widza rąk bohatera uznać można za pewien wariant pojawiającej się we wcześniejszych etiudach metamorfozy, polegającej na naruszeniu skali, która tym razem dotyczy „materialności” świata przedstawionego.
W Zagubionym Wacławek właśnie zachodzącą nieustannie w obrazowanych obiektach zmianę „jakościową” czyni najbardziej zagadkowym i pojemnym znaczeniowo chwytem. Warto zwrócić uwagę, że usychającymi w ostatniej scenie rękoma we wcześniejszym fragmencie filmu chłopiec niepowołanie dotykał tablicy odłożonej przez poruszyciela. Tablice te zrazu przypominają karty papirusu; dopiero po ich zapisaniu skryba przemienia je w kamień. W związku z tym zakończenie filmu ponownie zyskuje ambiwalentny wyraz: $z$ jednej strony bohaterowi towarzyszy zesłany mu „z góry” ptak, $z$ drugiej zaś jego ciało - ułożone przy stole w pozycji wcześniej zarezerwowanej dla mistrza - ulega rozpadowi. Kontakt $\mathrm{z}$ absolutem nie chroni więc mężczyzny przed zamieraniem, więcej nawet - być może to właśnie zbyt wielka bliskość tego, co święte, wywołuje nagłe obumieranie, które wydaje się tu zresztą naturalną częścią cyklu życia. Przestrzeń, w której rozgrywa się akcja Zagubionego, wypełniona jest bowiem ogromnymi, niepołączonymi ze sobą, mrocznymi pieczarami, skalnymi figurami. Figury te przypominają monstrualne, zastygłe ptaki, lekko poruszające się na wietrze. Pejzaż tworzący tło dla tej animacji sprawia więc takie wrażenie, jakby powoływane do życia niewinne stworzenia kończyły ostatecznie jako ogromne zastygłe bryły materii. Ponownie więc do głosu dochodzi tu $\mathrm{z}$ upodobaniem stosowany przez Wacławka środek artystyczny nazwany przeze mnie zmianą skali. Jego ślady, inaczej niż w dwóch poprzednich filmach, widoczne są od samego początku w obrazowaniu świata przedstawionego i rolą widza pozostaje zwrócić na to uwagę.

\section{Zakończenie}

Etiudy Grzegorza Wacławka stanowią świadectwo rosnącej dojrzałości artystycznej ich twórcy, kształtującego swój własny styl prowadzenia narracji. Niewątpliwie są one mocno zakorzenione w „egzystencjalnej” tradycji polskiej szkoły animacji, choć jednocześnie wydają się pozbawione charakterystycznego dla niej zaangażowania politycznego, a także piętrzą- 


\section{VARIA}

cego się wówczas w wielu animacjach absurdu (Sitkiewicz 2011, s. 171-172). Jak starałem się udowodnić, krótkie filmy Grzegorza Wacławka znakomicie poddają się różnym sposobom metaforycznego odczytania. W związku z ich paraboliczną formułą oraz oryginalnym wykorzystaniem przez twórcę ikoniczno-fabularnych metamorfoz, zwłaszcza tych nazwanych przeze mnie zmianą skali, zyskują one początkowo niedostrzegalną może dla widza głębię. Ukrytym bohaterem zrealizowanych przez reżysera w łódzkiej Szkole Filmowej etiud jest bez wątpienia czas - jego nieubłagane oddziaływanie na świat ludzi, którzy skazani są na powolne i nieodwracalne przemijanie. Często pojawiają się w tych animacjach wizualne motywy symbolizujące upływ czasu, zwłaszcza ukazywane w zbliżeniach przedstawienia twarzy męskich postaci w starości. Działania bohaterów, choć mozolne i mało spektakularne, niejako przeciwstawiają się otaczającej ich martwocie - tak rozumiem powracające często w utworach Wacławka sceny strugania, sklejania i składania w całość drobnych elementów.

\section{B I B L I O G R A F I A}

Giżycki M., 2000, Nie tylko Disney. Rzecz o filmie animowanym, Warszawa

Hendrykowski M., 1998, Sztuka krótkiego metrażu, Poznań

Kempna-Pieniążek M., 2013, Formuly duchowości w kinie najnowszym, Katowice

Sitkiewicz P., 2011, Polska szkoła animacji, Gdańsk 